\title{
Reproductive Tract Infections (RTI) among married women in Sri Lanka
}

\author{
Sathyadevi Herath ${ }^{1 *}$, Pushpa Fonseka ${ }^{2}$, Sujatha Samarkoon ${ }^{1}$ \\ From 17th International Symposium on HIV and Emerging Infectious Diseases (ISHEID) \\ Marseille, France. 23-25 May 2012
}

\section{Introduction}

Feminization of HIV epidemic, and increasing in HIV infection among house wives is seen in most of the world. Yet, community prevalence data on RTI are sparse in Sri Lanka, and little is known about rates among community women. The objective was to describe the prevalence and risk factors of RTI in women aged 22-49years, living in highly populated poor urban settlements of Sri Lanka.

\section{Methodology}

A community-based cross-sectional study was conducted among 770 married women living in 116 urban slums of Colombo city, Sri Lanka. Participants were interviewed on sociodemographic data, sexual history, knowledge on STI/ HIV, and condom use. Laboratory specimens were collected for thediagnosis of RTI.

Prevalence was calculated with corresponding 95\% confidence intervals (CI). Analyses of risk factors were carried outseparately for the outcomes of sexually transmitted infections: chlamydia, gonorrhoea, trichomoniasis; and endogenous infections:bacterial vaginosis (BV) and candida.

\section{Results}

Ninety three percent of women had single life time partner, only $9 \%$ was previously screened for STI/HIV. Condom use was mainly decided by the male partner and none of them used condom for prevention of STI/HIV.

Endogenous infections were relatively common [BV 8.6\% (95\% CI: 6.6.-10.6)candida $6.8 \%$ ( 95\%CI: 5.0-8.6)], and sexually transmitted infections (STI) were infrequent (1.1\%-95\% CI: 0.34-1.86).

\footnotetext{
* Correspondence: sathya_herath@yahoo.com

${ }^{1}$ National Sexually Transmitted Diseases, AIDS Control Program, Ministry Of Health, Sri Lanka

Full list of author information is available at the end of the article
}

Of the risk factors investigated none of the factors were associated with RTI on multivariate analysis.

\section{Conclusion}

Married women in this community had a low prevalence of RTI and risky sexual behavoiurs were infrequent. Most of the population burden of RTI is attributedto endogenous infections. However, education and outreach screening facilities are needed to reduce the stigma, embarrassment and lack of knowledge related to STI/HIV in order to facilitate screening and condom use.

\section{Author details}

${ }^{1}$ National Sexually Transmitted Diseases, AIDS Control Program, Ministry Of Health, Sri Lanka. ${ }^{2}$ University of Sri Jayawardenepura, Sri Lanka.

Published: 25 May 2012

doi:10.1186/1742-4690-9-S1-P45

Cite this article as: Herath et al:: Reproductive Tract Infections (RTI) among married women in Sri Lanka. Retrovirology 2012 9(Suppl 1):P45.

Submit your next manuscript to BioMed Central and take full advantage of:

- Convenient online submission

- Thorough peer review

- No space constraints or color figure charges

- Immediate publication on acceptance

- Inclusion in PubMed, CAS, Scopus and Google Scholar

- Research which is freely available for redistribution

\section{Biomed Central}

() 2012 Herath et al; licensee BioMed Central Ltd. This is an Open Access article distributed under the terms of the Creative Commons Attribution License (http://creativecommons.org/licenses/by/2.0), which permits unrestricted use, distribution, and reproduction in any medium, provided the original work is properly cited. 